\title{
The Image of Poland in Bulgarian Mass Media in 1990-1998 in the Light of Documents from the Archives of the Ministry of Foreign Affairs of the Republic of Poland
}

\author{
Obraz Polski w bułgarskich środkach masowego przekazu w latach 1990-1998 \\ w świetle dokumentów z Archiwum Ministerstwa Spraw Zagranicznych \\ Rzeczypospolitej Polskiej
}

\section{- Abstract •}

In this article, the image of Poland in the Bulgarian mass media was analysed. This image was presented on the basis of reports that were made by employees of the Polish Embassy in Sofia and sent to the Polish Ministry of Foreign Affairs. The Polish Embassy in Sofia had the biggest impact in promotion of the Polish themes in the Bulgarian mass media. Polish issues have been present in the Bulgarian mass media from the beginning of political transformation, although the media presented information from Poland with varying frequency. The popularity of Polish issues in the Bulgarian media grew significantly when important political and economic events took place in Poland, or when there were meetings on the highest level between representatives of both states. During this period, the mass media created a positive image of Poland, mainly regarding economic issues. Poland was recognised as the leader in the process of political and economic transformations among Central and Eastern Europe countries.

\section{- Abstrakt •}

Analizie poddano obraz Polski w bułgarskich mediach w latach 1990-1998. Obraz Polski zaprezentowano w oparciu o sprawozdania sporządzane przez pracowników polskiej placówki w Sofii i przesyłane do polskiego MSZ. Największy wkład w promowanie tematyki polskiej wśród mediów bułgarskich miała Ambasada RP w Sofii. Polska tematyka była obecna w bułgarskich mediach od początku przemian politycznych, choć media z różną częstotliwością prezentowały wydarzenia z Polski. Popularność problematyki polskiej wzrastała, gdy zachodziły w Polsce ważne wydarzenia polityczne i gospodarcze lub gdy dochodziło do wizyt na najwyższym szczeblu pomiędzy przedstawicielami obu państw. Media kształtowały w tym okresie pozytywny obraz Polski, zwłaszcza w kwestiach gospodarczych. Polska uznawana była pośród państw Europy Środkowo-Wschodniej za lidera w procesie przemian politycznych i gospodarczych. 
Keywords: Poland; Bulgaria; media; polonicum; international relations
Słowa kluczowe: Polska; Bułgaria; media; polonik; stosunki międzynarodowe

The subject of the research project is the image of Poland in the Bulgarian mass media in the period from 1990 to 1998. The analysis is based on the archival documents obtained from the Archives of the Ministry of Foreign Affairs of the Republic of Poland ${ }^{1}$ in 2018. Of the materials that were disclosed to me after submitting an appropriate request, any information about the image of Poland can only be found in the Bulgarian mass media covering the period from 1990 to 1998, despite the fact that I requested sources spanning the period of 1990-2018. The most recent documents that were made available dated back to 2007, but in the materials covering the period 1998-2007, I did not find any information about the image of Poland in the Bulgarian mass media. Certainly, in the custody of the Archives of the Ministry of Foreign Affairs there are other documents which contain such information, but I did not have access to them. In consideration of the above, I conclude that the materials that could have already been disclosed in a given year, i.e., those whose status changed from secret or confidential to declassified, were made available upon my request. Therefore, my analysis of the issue of the image of Poland in the Bulgarian media is based on the collection of documents covering the period from 1990 to 1998.

Information on the image of Poland in the Bulgarian mass media in 1990-1998 can be sourced mainly from political reports of the Polish Embassy in Sofia for the given period of activity (e.g., Political Report of the Polish Embassy in Sofia for 1992 of January 19, 1993; Political Report of the Polish Embassy in Sofia for 1993 of January 18, 1994). In the case of the report on the Embassy's activities in 1992, information on Poland in the Bulgarian media can also be found in a separate report on the press and information activities of the then First Secretary of the Embassy of the Republic of Poland in Sofia, Marian Orlikowski, and in a separate evaluation of the work of the mission in 1992 (Report on the Press and Information Activities in 1992 of January 15, 1993; Evaluation of the Work of the Embassy of the Republic of Poland in the Republic of Bulgaria in 1992 of October 13, 1993).

Due to the fact that the basis for the analysis are the memos constituting a kind of report, the review includes narratives and accounts of the authors of particular

${ }^{1}$ During a three-week search in the Archives of the Ministry of Foreign Affairs of the Republic of Poland, I obtained over 50 sets of documents, totalling over 1240 pages. I conducted the search in October 2018 in Warsaw. 
documents, in this case, the employees of the Embassy of the Republic of Poland, conveying information about Poland. Therefore, this paper does not provide direct analysis of information about Poland in the Bulgarian media, but an inference about the image of Poland based on Bulgarian media analysis by the employees of the Embassy. Therefore, I draw general conclusions about the image of Poland in the Bulgarian mass media as stated in the available reports.

The time span adopted for the study of the image of Poland in the Bulgarian media includes the first decade after the fall of Communism, basically the first eight years, i.e., 1990-1998. This initial period after the political transformation was undoubtedly of key importance for Poland, Bulgaria, as well as for other countries of the Central and Eastern Europe. It was then that all the post-communist states in this part of Europe assumed new directions of development in terms of their domestic and foreign policy. As independent and autonomous international players, these states began to shape their presence on the international stage. In this context, the Polish-Bulgarian relations also reached a new dimension.

In this paper, I want to examine how Poland was perceived in Bulgaria in the first years after the fall of Communism on the basis of foreign 'polonica' 2 published in the Bulgarian press, as well as in radio and television broadcasting. I will particularly seek the answers to the following questions: a) did the media form a positive/negative or neutral attitude towards the events taking place in Poland at that time? b) were there any events in Poland that were of particular interest to the Bulgarian public opinion or, on the contrary, were there any issues that did not attract attention of the Bulgarian media very much and why? c) were there any difficulties in presenting the image of Poland in the Bulgarian mass media? d) with what frequency did information about Poland appear in the Bulgarian media? e) what was the general perception of Poland in the Bulgarian media at that time? In other words, what was the image of Poland created in the Bulgarian mass media at that time? This issue is interesting also for two other reasons. First of all, it is generally known that the media shape public opinion and consequently they also influence the views of the society. Therefore, it is interesting how Poland could have been

${ }^{2}$ Foreign polonica are publications issued outside of Poland, meeting at least one of the following criteria: a) the language of the publication is Polish, also translated - provided that the language of the original text is Polish; b) the contents concerns Poland and Poles or is dedicated to Poles or addressed to Poles; c) the author of the publication is of Polish origin. See entry in: Sternik (n.d.). In a broader sense, a polonicum is defined as any written document, object or place of Polish origin, or a place thematically connected with Poland, which is found on the territory of Poland or abroad. Polonica are closely connected with the legacy of the Polish nation and define the material and spiritual culture of Poles. See entry in: PWN (1966). 
perceived by the Bulgarian society in that crucial period based on the information available in the materials disclosed to me. In the context of the chosen issue, it is also interesting to emphasise the substantial contribution of the Polish Embassy in Sofia and various cultural centres associating Poles in Bulgaria (e.g., the Polish Institute, Władysław Warneńczyk Polish Cultural and Educational Association) in the promotion of Polish affairs abroad (in Bulgaria).

In order to answer the questions presented above, it will be useful to acknowledge various conditions that influenced the overall image of Poland reflected in the media in the first decade after the collapse of Communism. By analysing the largest possible group of factors, it will be possible to discover how often the Bulgarian media were interested in Poland, what topics they focused on or did not cover, what Polish issues they highlighted, or whether there were any difficulties in presenting the image of Poland at that time. The application of factor analysis (Pietraś, 1997, pp. 26-29) will allow for identification, classification and prioritisation of factors that influenced the image of Poland in the Bulgarian media in a given period. The historical method (Miśkiewicz, 1985) will also be useful as it will serve to outline the general context of events in the history of Poland and Bulgaria, which may have influenced the quality and frequency of foreign polonica in Bulgaria over a specific period of time.

The Embassy of the Republic of Poland has been active in promoting Polish themes in the Bulgarian mass media. It has been cooperating in this field with various cultural centres associating Poles in Bulgaria (the Polish Institute, Władysław Warneńczyk Polish Cultural and Educational Association). One of the tasks of the Polish mission is to create a favourable image of Poland in the Bulgarian media. The embassy's own activities in this field include press conferences, briefings and meetings organised by the embassy for Bulgarian journalists. The Polish Embassy regularly prepares and submits memos on the image of Poland in the Bulgarian mass media to the competent department of the Ministry of Foreign Affairs of the Republic of Poland. The examples of such memos or reports include annual political reports of the Embassy.

In the analysed period, i.e., between 1990 and 1998, the authors of the reports drew particular attention to several important issues related to the Bulgarian media which affected the image of Poland in the Bulgarian mass media.

They repeatedly emphasised that the Bulgarian media lacked a consistent information policy with regard to foreign countries. Neither newspapers, radio, nor the Bulgarian Telegraphic Agency had a permanent correspondent in Poland in the initial period of political transition. As a result, the Bulgarian media acquired 
information mainly from third-party sources, such as the Reuters agency. Another problem was that most editorial offices did not have specialists in international and country-specific issues. Therefore, the image of Poland presented in the media to a large extent was rather simplified. Moreover, specifically due to the absence of correspondents and publicists specialising in Polish issues, a constant flow of information about Poland was significantly impeded. At the beginning of the systemic transformation, the best and most accurate information and reports from Poland were provided by the radio, owing to the journalist of Horizon radio Channel 1 Veselina Belcheva (Political Report of the Polish Embassy in Sofia for 1991 of January 1992; Political Report of the Polish Embassy in Sofia for 1992 of January 19, 1993). However, I find the information about the absence of Bulgarian correspondents in Poland at the beginning of the political changes inaccurate. For instance, the document Evaluation of the Work of the Embassy of the Republic of Poland in the Republic of Bulgaria in 1992 states that two persons accredited as permanent foreign correspondents were staying in Warsaw in the years 1992/1993. These were Veselin Jankov of BTA agency and Galia Simeonova-Konach of the $21^{s t}$ Century weekly. The Kontinent daily also applied for accreditation of their correspondent (Violeta Savova). In comparison with Bulgaria, there were also 3 Hungarian correspondents, while Romania did not have any journalist in Poland at that time (Evaluation of the Work of the Embassy of the Republic of Poland in the Republic of Bulgaria in 1992 of October 13, 1993).

In addition, the authors of the report repeatedly drew attention to the problematic issue faced by the Bulgarian media, namely, the considerable politicisation of the press. Most of the Bulgarian dailies and other periodicals were affiliated with specific political parties and groups, and consequently, most of the information and commentaries were biased according to ideological requirements, i.e., they were used instrumentally for specific political purposes. As a result of that state of affairs, the image of Poland and other countries in the Bulgarian press was not free of contradictions and was unequal. There was a lack of in-depth analysis and proper coverage of the events taking place in our country at that time. The published information mainly concerned political changes and economic reforms (e.g., the Balcerowicz Plan, the presidential elections of 1995). However, the information was limited and fragmentary. This situation often led to misunderstandings and gaffes by leading figures in Bulgarian public life. As an example, the authors of the reports cited one of the publications in the socialist-owned daily Duma. The article reported that the parliamentary elections of October 1991 in Poland were won 
by left-wing forces ${ }^{3}$. The authors of the report for 1992 also quoted Filip Dimitrov, chairman of the Union of Democratic Forces (UDF), who stated in parliament that "not even a mouse can make its way through the fragmented Polish Sejm, let alone a bill".

According to the report for 1994, the most reliable, comprehensive and consistent accounts of Polish events was provided by the Bulgarian Socialist Party (BSP) newspaper Duma and the daily Standard, where the deputy editor-in-chief was Maxim Bechar, a long-time correspondent of Robotnitchesko Delo in Poland. Such newspapers as Duma, Standard, Kontinent, or $21^{\text {st }}$ Century, as well as the state radio Horizon and the private radio station Darrik were particularly favourable and open to the Polish affairs (Political Report of the Polish Embassy in Sofia for 1991 of January 1992; Political Report of the Polish Embassy in Sofia for 1992 of January 19, 1993, p. 15; Political Report of the Polish Embassy in Sofia for 1994 of January 27,1995$)$.

Due to the already mentioned considerable politicisation of the Bulgarian press, the authors of the reports repeatedly pointed out that political events taking place in Poland were interpreted in the Bulgarian media in an ambiguous manner. For example, the Embassy's report for 1992 states that "News about Poland and from Poland still appear frequently (more often than, e.g., from Hungary, the Czech Republic, Slovakia, or Romania), but they are random, haphazard and do not create any image of Poland or the processes taking place in it, although our country is still perceived as a precursor, or even as the avant-garde of the current changes in Eastern Europe" (Political Report of the Polish Embassy in Sofia for 1992 of January 19, 1993). However, according to the authors of the 1993 report, "[...] the politicised Bulgarian press is dominated by the mood of waiting for events that can be interpreted and used in a less ambiguous way. For the average reader, the image of the Polish political scene is vague and unclear. The opinion on the economic situation in Poland is much better. In all publications, Poland is regarded as the leader of Central and Eastern Europe. Especially the economic growth achieved in our country in spite of decreasing tendencies in Western Europe is emphasised" (Political Report of the Polish Embassy in Sofia for 1993 of January 18, 1994, p. 29).

3 These were the first completely free parliamentary elections in Poland after 1989. They were won by the Democratic Union, a centrist party founded by Tadeusz Mazowiecki. As a result of the electoral law of the time, there was no electoral threshold in the elections. This led to a situation in which almost 30 groups entered the parliament. As a result, the political scene was highly fragmented and there were significant problems with forming a government. 
At the beginning of the political transition, there was not much interest in Polish affairs in the Bulgarian media. The authors of the report for 1992 pointed out that this was due to the lack of high-level political contacts between Poland and Bulgaria. It is worth emphasising that both countries established political dialogue up to the level of presidents in 1994. This is evidenced by the visit of Bulgarian President Zhelyu Zhelev to Warsaw in 1993 and the visit of Polish President Lech Wałęsa to Sofia a year later. Until then, the meetings of the representatives of the two countries at a lower level, as well as the topics discussed during such meetings were not in the spotlight of the Bulgarian media. In spite of this, several interviews with Poles were recorded for Bulgarian television and radio in 1992, for example, with Tadeusz Wasilewski (the then Ambassador of the Republic of Poland in Sofia), Marian Krzaklewski (during his visit as chairman of "Solidarity"), or MP Hanna Suchocka, before she was appointed the Prime Minister. Moreover, the Polish Embassy organised an interview with President Zhelev and Vice-President Blaga Dimitrova for the Gazeta Wyborcza newspaper and an interview with President Zhelev and Bulgarian Foreign Minister Stoyan Ganev for the Rzeczpospolita daily. On February 15, 1993, an interview with the Polish President Lech Wałęsa was published in the $21^{\text {st }}$ Century weekly. It was the first interview with the Polish President for the Bulgarian press (Political Report of the Polish Embassy in Sofia for 1992 of January 19, 1993; Evaluation of the Work of the Embassy of the Republic of Poland in the Republic of Bulgaria in 1992 of October 13, 1993).

Over the period of time under scrutiny, the Bulgarian mass media were interested in Polish issues especially in the context of the socio-political situation in our country, in the context of economic issues, as well as following the process of Poland's integration with the European Union (EU). The Embassy of the Republic of Poland pointed out that the Bulgarian press, while presenting this subject, sought analogies between our country and Bulgaria in the context of political events and the situation in Bulgaria at that time. It must be remembered that for Bulgarians, the beginning of the 1990s was also a significant period of deep political, economic and social changes. At that time, Poland appeared to spearhead the process of political and economic changes in Central and Eastern Europe, followed not only by Bulgaria, but also by other countries in this part of Europe. Poland was therefore a kind of a rolemodel, which - according to available reports - Bulgaria wanted to use. Polish affairs were published in the Bulgarian media also indirectly, e.g., when discussing events important for Bulgarians, such as the conflict in the former Yugoslavia. 
One political event in Polish politics noted by the Bulgarian media was the parliamentary elections held in September $1993^{4}$. At that time, the Bulgarian press tried to analyse the new order of the Polish political scene. It published interviews with President Lech Wałęsa (TV programme Nabludatel, October 22, 1993), former Prime Minister Jan Krzysztof Bielecki (in the 21 $1^{\text {st }}$ Century weekly), senator Zbigniew Romaszewski (in the Detajli weekly). The authors of the report underlined that the election results in Poland surprised and even confused public opinion in Bulgaria. The mass media, sympathising with UDF and other centrist and rightwing parties which ruled in Bulgaria at that time, considered the victory of the left wing in Poland as a sign of "re-communisation" of Central and Eastern Europe. They also expressed concern that the results of the Polish elections could have a negative impact on the then unstable political situation in Bulgaria. The strategy of continuing economic reforms adopted by the Polish government was incomprehensible for Bulgarian publicists, and at the same time it was politically inconvenient for Bulgarians, taking into account the then bipolar balance of power in the country (UDF-BSP). The left-wing press, which, analysing the political situation in Poland and the SLD's victory, predicted a Polish turn towards Russia and restraint in contacts with the Western Europe, was also disoriented (Political Report of the Polish Embassy in Sofia for 1993 of January 18, 1994).

All major events taking place in 1994 in Poland were reported by the Bulgarian media, particularly by press and on the radio, but also by television to a lesser extent. Bulgarian media were especially interested in events with international overtones. The media commented on changes on ministerial positions, the government of Prime Minister Pawlak, relations between President Wałęsa and the ruling coalition, and local elections in Poland. As far as economic issues are concerned, the press covered the following topics: positive evaluation of the Polish economy by international institutions, or the agreement on the reduction of the Polish debt (London Club). As regards Polish foreign policy, the Bulgarian media were particularly interested in the issues of relations with the Visegrad Group (V4), notification of Poland and Hungary's accession to the EU, the Poland-NATO relations (including the Partnership for Peace programme, NATO training exercise in Poland), the Weimar Triangle, or the Poland-Russia relations (in the context of Prime Minister Pawlak's visit to Moscow). The most frequent and widely commented event was the

${ }_{4}$ As a result of the elections, 8 groups entered the Polish Parliament. The winner was the Democratic Left Alliance (SLD) and the Polish Peasant Party (PSL). The Democratic Union came third. The newly formed government was chaired by Waldemar Pawlak, PM. 
visit of President Wałęsa (Political Report of the Polish Embassy in Sofia for 1994 of January 27, 1995).

One of the most important political events also commented by the Bulgarian media was the presidential election in Poland in 1995. According to the authors of the 1995 report, this is evidenced by the fact that almost all major editorial offices, including public television and radio stations, sent their journalists to Warsaw for both rounds of the election. High interest in the event was also confirmed by the very high turnout at press conferences organised at the Embassy both before and after the elections. Aleksander Kwaśniewski's election victory was widely reported in the Bulgarian press. The Duma daily and other mass media affiliated with the BSP evaluated the victory of A. Kwaśniewski in presidential elections as a success of the left. For this reason, the issue of the Duma of November 21, 1995 even placed above the vignette of the paper on the first page a large title "We Shake Hands with the Polish Left" (Political Report of the Polish Embassy in Sofia for 1995 of January 25, 1996, p. 40). In turn, the media affiliated with the UDF and other opposition groups assessed A. Kwaśniewski's victory as unfavourable for Poland and for the entire transformation in all countries of the former socialist bloc. According to the report for that year, a similar opinion was also expressed by some politicians. The reports from the meeting of the BSP Executive Office a week after the elections included opinions of the party activists that the outcome of the vote in Poland was "a key moment for the development of Eastern Europe". It seems justified that the issue of Polish elections was in the focus of the Bulgarian press at that time, as the Bulgarians were also facing presidential elections in the near future.

In the following year, the Bulgarian media continued to show interest in Poland. Furthermore, the report for 1996 states that "in the second half of the year, Poland became unquestionably the most frequently and positively depicted country of Central and Eastern Europe, presented to the public opinion as an example of a well managed political transformation, decisive and deep economic reforms and changes in social consciousness, especially in mentality and performance of the old and the new political elites. Never before has Poland enjoyed such a good reputation in Bulgaria, although - as the Polish Embassy in Sofia has been pointing out for several years - our country has won widespread affection in Bulgaria and is regarded as a catalyst for change in the former socialist bloc" (Political Report of the Polish Embassy in Sofia for 1996, p. 41). The Embassy of the Republic of Poland also reckoned that despite many "shortcomings" of the Bulgarian press and many reservations about the quality and accuracy of publications on Polish affairs, a positive impression is made both by the frequency of information publications in the media, as well as their positive reception. According to the Embassy's publication 
statistics at that time, the Bulgarian media published an average of 2-3 news releases on Polish life every day.

The Embassy reported that the most discussed events in the media for the next two years, 1996 and 1997, were undoubtedly the meetings between President Kwaśniewski and Petar Stoyanov, initially still as a presidential candidate in Bulgaria and later already as a president. The Embassy also informed that during the entire 1996 and 1997 there were no definitely negative opinions on the processes taking place in Poland in the Bulgarian press. In other words, the positive image of Poland as a leader of the political and economic transformation did not change in Bulgaria during that period. Especially the meeting of the two politicians at the end of 1996 had a strong political effect, as the report claimed - it contributed to Stoyanov's victory in the presidential elections. Stoyanov's visit to Warsaw in October 1996 was perceived as one of the most important meetings which resulted in Stoyanov's personal electoral success. That visit was perceived as an occasion for the Polish President to show his support for the policy and candidacy of P. Stoyanov. It was estimated at the time that the meeting in Warsaw gave Stoyanov an additional $3-8 \%$ advantage in the presidential election. As a result of the election, P. Stoyanov defeated Ivan Marazov, the Socialist candidate for the presidential office. According to the report, many articles at that time attempted to analyse the differences in the Polish and Bulgarian approaches to the transformation, highlighting Stoyanov's words after his visit to Warsaw, "I told the Polish president that I envy Poland its reformed socialists" (Political Report of the Polish Embassy in Sofia for 1996, p. 42; Political Report of the Polish Embassy in Sofia for 1997 of February 3, 1998; Urgent Note Regarding the Substantive and Program Assumptions for the Official Visit of the President of the Republic of Bulgaria Petar Stoyanov to Poland of February 13, 1997).

As regards Poland's economic successes, in 1996 the Bulgarian mass media massively reported information about the Polish consumption boom. According to the authors of the report, this situation was shocking for the Bulgarians, who at that time were experiencing a deep economic crisis in the country. Another economic event commented on at the time was also the admission of Poland to the OECD, called "the club of the richest countries of the world" (Political Report of the Polish Embassy in Sofia for 1996).

The topics in the focus of the Bulgarian media in the analysed period were also Poland's integration into the EU, NATO, and cooperation within the Visegrad Group (V4). At the initial stage of the talks between Poland and the EU and NATO, the Bulgarian authorities were quite sceptical about that integration process. They were equally sceptical about Poland's cooperation with the Visegrad 
Group. According to numerous reports and analyses in the Bulgarian press, Bulgarians feared and even accused NATO or the EU of favouring Poland on its way to integration with those organisations. Thus, they accused NATO and the EU of marginalising Bulgaria in the integration process, due to the fact that the transformation process was much slower in Bulgaria than in Poland. The decision on restructuring and rearming the armed forces of the V4 countries in order to prepare them for entry into NATO, Bulgaria considered as a sign of lack of solidarity with countries less advanced in their talks with the EU and NATO. Thus, the authors of the reports drew attention to the rather unfavourable attitude of the Bulgarian press towards the $\mathrm{V} 4$ at the beginning. The group was initially treated not as a partner, but as a competitor. It should also be emphasised that in Bulgaria itself, the issue of NATO enlargement was heavily commented on and undermined by the ruling socialist party (BSP) at the time. The particular sensitivity of Bulgarians to the issue of NATO enlargement can be observed in an interview with Prime Minister Zhan Videnov (BSP) in May 1995 in Trud, the most popular and objective daily newspaper at the time. In that interview, the Prime Minister said that "the buzz around NATO enlargement concerns Poland exclusively", and stated that he was disappointed that the West did not respond to the fact that Poland was provoking Russia by conducting accession negotiations. The issue of integration into CEFTA and CEI was received with similar ambiguousness in Bulgaria. At the beginning, Bulgaria showed reservation towards those organisations and Poland's cooperation within them. According to the reports and news releases in the Bulgarian press, that distrust of the Bulgarians towards CEFTA and CEI was overcome when Bulgaria became a member of those two organisations and started negotiations with Poland on the creation of a free trade area between the two countries (Political Report of the Polish Embassy in Sofia for 1993 of January 18, 1994; Political Report of the Polish Embassy in Sofia for 1995 of January 25, 1996; Political Report of the Polish Embassy in Sofia for 1996). However, it needs to be noted briefly that the initially hostile attitude of the Bulgarians towards CEFTA was due to the fact that Bulgaria's accession to this organisation was partly connected with Poland's approval of that accession. In turn, since the beginning of the democratic changes, Poland has been demanding from Bulgaria the repayment of ruble debt and the repayment of NBP deposits. Poland made Bulgaria's admission to CEFTA conditional on the repayment of those deposits. Thus, political issues had a great influence on the presence of Poland in the Bulgarian press (Political Report of the Polish Embassy in Sofia for 1998 of January 25, 1999).

Polish issues were presented in Bulgarian media also indirectly, e.g., amid discussions on some events important for Bulgarians, such as the conflict in former 
Yugoslavia or Kosovo (Political Report of the Polish Embassy in Sofia for 1995 of January 25, 1996; Political Report of the Polish Embassy in Sofia for 1998 of January 25, 1999). It needs to be emphasised that the mid-1990s was a difficult period for Bulgaria, but also for the other countries of the Balkan region due to the open conflict in the former Yugoslavia. In view of this dangerous situation in the region, new security guarantees such as NATO presence in the Balkans had to be established as soon as possible. Bulgaria, which had rather sceptical attitude towards the Alliance during the BSP government, changed its approach to NATO following the change of government and the seizure of power by pro-democracy (UDF) parties. Since then, it has made efforts to expedite Bulgaria's accession to the Alliance. Bulgaria's difficult international position at the time was further complicated by the embargo imposed on Serbia. As a consequence of the sanctions imposed on Serbia, Bulgaria was completely blocked and the country fell into deep economic isolation. The conflict in the former Yugoslavia cut the country off from the communication channels with Western Europe. In the context of the Balkan conflict, the Bulgarian press was interested in Poland's marking its presence in the mission by the former Polish Prime Minister Tadeusz Mazowiecki to Bosnia, who as the UN special envoy reported on the human rights situation in the Balkans. The Bulgarian media also commented on Polish efforts to put the Kosovo conflict down. In this context, the media were interested in the activities of the OSCE. At the time Bronisław Geremek was Chairman of the OSCE, and owing to him an agreement was signed with Belgrade on the establishment of an OSCE humanitarian verification mission in the area. Bulgaria referred to this event with great appreciation and frequently commented on it in the media.

Much less information about Poland reached the Bulgarian media in the first half of 1998 (Political Report of the Polish Embassy in Sofia for 1998 of January $25,1999)$. The reason for this state of affairs was the fact that at that time Poland strongly required Bulgaria to repay its NBP deposits and made Bulgaria's admission to CEFTA conditional on that. Moreover, according to the report for 1998, probably another factor was the decision to postpone the visit of the Minister of Foreign Affairs Nadezhda Mikhaylova to Poland.

In conclusion, at the beginning of the political transformation there was not much interest in Polish affairs in the Bulgarian media, although a few interviews with Poles for the Bulgarian TV, radio and press reached the public. Polish press also published several interviews with Bulgarians. The reason for the low interest in Polish affairs at that time was the lack of high-level political contacts between Poland and Bulgaria. It was only in 1994 that a political dialogue developed, up to the presidential level, between the two countries. In general, the Bulgarian press wrote 
in positive terms about Poland, although the reports from Warsaw rarely made headlines. The reason for that was also the interest of the Bulgarian media mainly in Yugoslav and Russian topics.

The biggest contribution to the promotion of Polish issues in the Bulgarian media was made by the Polish Embassy in Sofia and cultural centres for Poles in Bulgaria, such as the Polish Institute. One of the tasks of the Polish mission has been and still is to create a favourable image of Poland in the Bulgarian media. The Polish mission's own activities aimed at promoting Polish issues include press conferences, briefings and meetings organised by the mission for Bulgarian journalists. Over the analysed period, it was the Bulgarian press and radio that most often commented on the "Polish issues". Bulgarian state television devoted much less attention to Poland. This was largely due to the numerous financial problems that the Bulgarian television was struggling with at the time. By virtue of the efforts of the Polish Embassy in Sofia, for example, in 1994, Bulgarian television broadcast a film free of charge on the occasion of the $50^{\text {th }}$ anniversary of the Warsaw Uprising (Political Report of the Polish Embassy in Sofia for 1994 of January 27, 1995).

The popularity of Polish issues in the Bulgarian media grew following important political events taking place in Poland or when subsequent stages of Leszek Balcerowicz's economic reforms were implemented. The awareness of Polish issues also increased when the most important political figures visited Poland or Bulgaria. That was the case with the visit of Polish Deputy Prime Minister L. Balcerowicz to Sofia in 1991, the visit of President Wałęsa in 1994 and President Aleksander Kwaśniewski in 1996. The popularity of Poland in the Bulgarian media was also marked when Poland was visited by Bulgarian President Zhelyu Zhelev in early 1993 and by President Petar Stoyanov in late 1996 and early 1997.

At the beginning of the political transition, the Bulgarian media lacked a consistent information policy with regard to foreign countries. From the available reports it can be concluded that the Bulgarian media at the time did not have a permanent correspondent in Poland and thus obtained information mainly from third-party sources. Many editorial offices also did not have specialists in Polish issues. Therefore, the image of the events taking place in Poland as presented in the media was simplified to a large extent.

Moreover, there was a certain discrepancy between the coverage of the political situation in Poland in the Bulgarian press which resulted from its strong politicisation. The authors of the reports repeatedly stressed that the same events taking place on the Polish political scene were presented and interpreted differently in the Bulgarian press. For example, according to Duma - a socialist daily - the good economic results in Poland were the effect of good administration by the left-wing 
government rather than the result of reforms of L. Balcerowicz. Moreover, the successes of the Polish right-wing government even irritated the editors of the said newspaper, which manifested itself in various attempts to discredit Polish successes and highlight the problems. Therefore, the picture of the Polish political situation in the Bulgarian press was rather ambiguous.

The account of the Polish economic situation in the Bulgarian media was definitely clearer. According to available reports, all Bulgarian mass media reported on the Polish model of economic reforms and recovery from communism in positive terms. It can be concluded that throughout the analysed period Poland was treated by other countries in the region as a reference or a model in the domain of state economy.

\section{References:}

Miśkiewicz, B. (1985). Wstęp do badań historycznych. Warszawa-Poznań: Państwowe Wydawnictwo Naukowe.

Pietraś, J.Z. (1997). Teoria stosunków międzynarodowych. In: T. Łoś-Nowak (Ed.). Wspótczesne stosunki międzynarodowe (pp. 26-29). Wrocław: Wydawnictwo Uniwersytetu Wrocławskiego.

PWN (1966). Polonica. In: Wielka Encyklopedia Powszechna PWN. Vol. 8 (p. 837). Warszawa: PWN.

Sternik (n.d.). Polonika zagraniczne. In: Sternik. Stownik terminologiczny z zakresu bibliografii i katalogowania. Retrieved June 24, 2021 from: http://sternik.bn.org.pl/vocab/ index.php?tema $=1581 \& /$ polonika-zagraniczne.

\section{Archival sources:}

a. Political Reports (1991-1998):

Archive of the Ministry of Foreign Affairs of the Republic of Poland, Department of Europe 1 (DE1), Acquisition 13/95, File III, Folder 12, Doc. No.: DE.R.242-1-91, Political Report of the Polish Embassy in Sofia for 1991 of January 1992, Sofia.

Archive of the Ministry of Foreign Affairs of the Republic of Poland, Department of Europe 1 (DE1), Acquisition 15/95, File VII, Folder 12, Doc. No.: DE.B.242-1-92, Political Report of the Polish Embassy in Sofia for 1992 of January 19, 1993, Sofia.

Archive of the Ministry of Foreign Affairs of the Republic of Poland, Department of Western Europe (DEZ), Acquisition 35/2001, File I, Folder 12, Doc. No.: B-22-6-93, Political Report of the Polish Embassy in Sofia for 1993 of January 18, 1994, Sofia.

Archive of the Ministry of Foreign Affairs of the Republic of Poland, Department of Central and Eastern Europe/Department of Central and Southern Europe (DEŚiW/ DEŚiP), Acquisition 36/2001, File III, Folder 12, Doc. No.: B-22-7-94, Political Report of the Polish Embassy in Sofia for 1994 of January 27, 1995, Sofia. 
Archive of the Ministry of Foreign Affairs of the Republic of Poland, Department of Central and Southern Europe/Department of Central and Eastern Europe (DEŚiP/ DEŚiW), Acquisition 38/2001, File I, Folder 12, Doc. No.: B-22-5-96/3, Political Report of the Polish Embassy in Sofia for 1995 of January 25, 1996, Sofia.

Archive of the Ministry of Foreign Affairs of the Republic of Poland, Department of Central and Southern Europe/Department of Central and Eastern Europe (DEŚiP/ DEŚiW), Acquisition 38/2001, File I, Folder 12, Doc. No.: B-22-5-96, Political Report of the Polish Embassy in Sofia for 1996, Sofia.

Archive of the Ministry of Foreign Affairs of the Republic of Poland, Department of Central and Southern Europe (DEŚiP), Acquisition 13/2002, File I, Folder 12, Doc. No.: B-242-1-97, Political Report of the Polish Embassy in Sofia for 1997 of February 3, 1998, Sofia.

Archive of the Ministry of Foreign Affairs of the Republic of Poland, Department of Europe (DE), Acquisition 31/2003, File I, Folder 12, Doc. No.: B-242-1/98/pf86, Political Report of the Polish Embassy in Sofia for 1998 of January 25, 1999, Sofia

\section{b. Other documents:}

Archive of the Ministry of Foreign Affairs of the Republic of Poland, Department of Western Europe/Department of Central and Southern Europe (DEZ/DEŚiP), Acquisition 35/2001, File I, Folder 12, Doc. No.: B-22-7-93, Report on the Press and Information Activities in 1992 of January 15, 1993, Sofia.

Archive of the Ministry of Foreign Affairs of the Republic of Poland, Department of Western Europe/Department of Central and Southern Europe (DEZ/DEŚiP), Acquisition 35/2001, File I, Folder 12, Doc. No.: B-22-7-93, Evaluation of the Work of the Embassy of the Republic of Poland in the Republic of Bulgaria in 1992 of October 13, 1993, Warsaw.

Archive of the Ministry of Foreign Affairs of the Republic of Poland, Department of Central and Southern Europe (DEŚiP), Acquisition 13/2002, File I, Folder 12, Doc. No.: DEZ.B-220-1-97, Urgent Note Regarding the Substantive and Program Assumptions for the Official Visit of the President of the Republic of Bulgaria Petar Stoyanov to Poland of February 13, 1997, Warsaw. 